\title{
Conulariids and Sphenothallus (Cnidaria, Medusozoa) from the Tonggao Formation (Lower Ordovician, China)
}

\author{
Heyo VAN ITEN, LUCy A. MUIR, JOSEPH P. BOtTING, Zhang YUAN-DONG \& JIH-PAI LIN
}

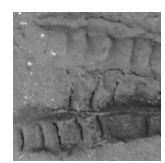

\begin{abstract}
Conulariella sp. and possibly one other conulariid species occur in close association with Sphenothallus sp. in the lower part of the early Floian Tonggao Formation near the town of Sandu, Guizhou Province, China. This is the only known occurrence of Conulariella in Early Ordovician rocks outside of Bohemia (Perunican terrane), and also the first report of Sphenothallus from the Ordovician of China. The apertural margin of Conulariella appears to have been mostly straight, and apertural lappets probably were not present in this genus. Some Tonggao conulariids may have attached to orbiculoid brachiopods in life. Based on the most recent palaeogeographical reconstructions of Gondwana and associated terranes, Conulariella could have had a dispersal path along the Gondwanan margin. $\bullet$ Key words: Conulariella, Sphenothallus, conulariids, Ordovician, South China.
\end{abstract}

VAN ITEN, H., MuiR, L.A., BotTing, J.P., ZHANG, Y.D. \& Lin, J.P. 2013. Conulariids and Sphenothallus (Cnidaria, Medusozoa) from the Tonggao Formation (Lower Ordovician, China). Bulletin of Geosciences 88(4), 713-722 (5 figures). Czech Geological Survey, Prague. ISSN 1214-1119. Manuscript received December 5, 2012; accepted in revised form July 22, 2013; published online August 14, 2013; issued October 31, 2013.

Heyo Van Iten (corresponding author), Department of Geology, Hanover College, Hanover, IN 47243, U.S.A; and Cincinnati Museum Center, Research Associate, Department of Invertebrate Paleontology, 1301 Western Avenue, Cincinnati, OH 45203, U.S.A.; vaniten@ hanover.edu • Lucy A. Muir, Joseph P. Botting, Zhang Yuan-Dong \& Jih-Pai Lin, State Key Laboratory of Palaeobiology and Stratigraphy, Nanjing Institute of Geology and Palaeontology, Chinese Academy of Sciences, 39 East Beijing Road, Nanjing 210008, China; lucy@asoldasthehills.org, acutipuerilis@yahoo.co.uk, ydzhang@nigpas.ac.cn,jplin@nigpas.ac.cn

Conulariids (Cnidaria, Scyphozoa; Van Iten et al. 2006) are found in the geological record from the Ediacaran to the Triassic (Leme et al. 2008), and the related Sphenothallus (Cnidaria, Scyphozoa or Hydrozoa; Van Iten et al. 1992) is known from the Cambrian to the Permian (Fatka et al. 2012). Conulariids generally are rare in the Ordovician, and they appear to exhibit marked faunal provincialism (Van Iten \& Vyhlasová 2004). In this paper we describe Sphenothallus sp. and two conulariids, Conulariella sp. and an indeterminate conulariid, from the Lower Ordovician Tonggao Formation of Guizhou Province, South China.

Conulariella Bouček, 1928, originally described from Early Ordovician strata of Bohemia, is a highly distinctive genus characterized by (1) a strongly rectangular transverse cross section and (2) nearly rectilinear transverse ribs lacking any definition of a facial midline (e.g., Moore \& Harrington 1956a, fig. 45). Bouček (1928) recognized three species, namely the type species $C$. robusta (Barrande, 1867), C. purkynei (Želízko, 1911) and C. sulca (Želízko, 1921). All three species range from the earliest Floian to the latest Darriwilian (Van Iten \& Vyhlasová
2004). More recently, Pillet \& Beaulieu (1998) described C. purkynei, C. minima Pillet \& Beaulieu and Conulariella sp. from the Middle Ordovician (Darriwilian) Schistes à nodules d'Angers of the Armorican Massif (northwestern France). The small shelly fossil Hexaconularia He \& Yang 1986, currently known only from basal Cambrian strata of South China (Conway Morris \& Chen 1992), appears to be most similar to Conulariella (Van Iten et al. 2010), and indeed these two genera may be nearest relatives.

The present study constitutes the first definite report of Conulariella in China as well as the first occurrence of this conulariid genus in Early Ordovician strata outside of Bohemia (Perunica). This is also the first report of Sphenothallus in the Ordovician of China. As well as expanding our knowledge of the stratigraphical and palaeogeographical distribution of these two medusozoan genera, the new material from China provides additional evidence regarding the locations of conulariid-bearing terranes during Early Ordovician times and/or the dispersal capacity and life history of conulariids and Sphenothallus. 


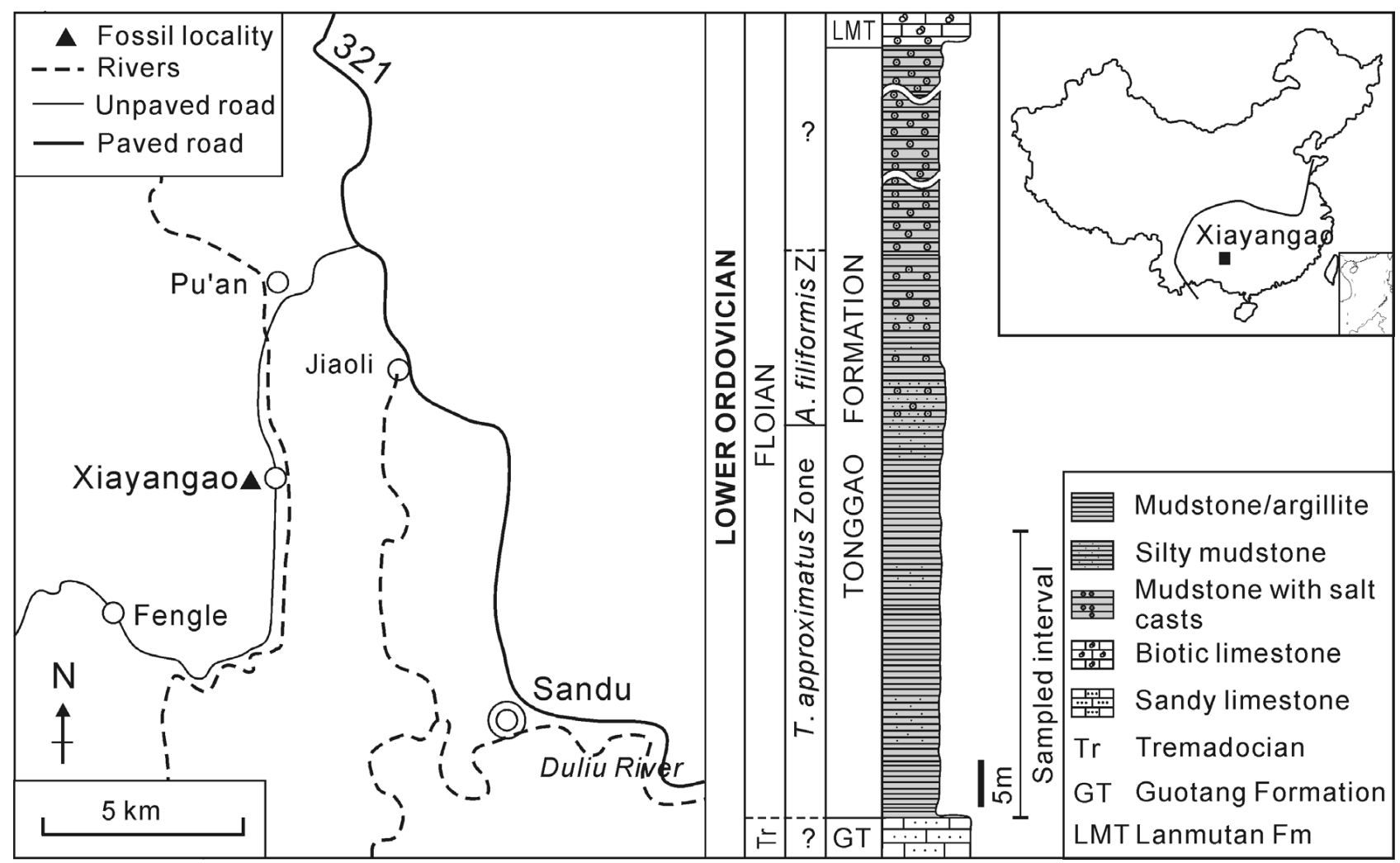

Figure 1. Locality map showing the Xiayangao section through the Tonggao Formation (Lower Ordovician, lower Floian). Inset map shows the location of the section within China.

\section{Material and methods}

The present study is based on direct examination of 51 conulariid and 18 Sphenothallus specimens from a single section through the Tonggao Formation near the town of Sandu, Guizhou Province, China (Fig. 1; see also discussion below). The specimens occur in blue-gray shale or yellow-green shale or siltstone, and were subjected to minimal preparation and cleaning with water and a soft brush. Specimens were examined and photographed using reflected light and scanning electron microscopy. Backscattered and secondary SEM imaging was performed using a Gemini Leo 1530VP Environmental Scanning Electron Microscope and a Hitachi S-3000N Scanning Electron Microscope. Operating voltage in backscattered electron mode was $15-20 \mathrm{kV}$. Preservation of conulariid and Sphenothallus shell material was studied using a combination of EDAX and elemental mapping. EDAX analysis was done using an Inca X-sight device made by Oxford Instruments. Light photography was performed with a Nikon D80 digital SLR camera, combined with a Sigma $105 \mathrm{~mm}$ f2.8 macro lens and extension tubes, utilising direct sunlight where possible and external, reflected flash at higher magnification. All specimens have been deposited in the Nanjing Institute of Geology and Palaeontology (NIGP), specimen numbers NIGP 156022 to NIGP 156067.

\section{Stratigraphical and palaeoenvironmental context}

The rock exposure from which the Tonggao Formation conulariids and Sphenothallus were obtained is located on the track between Xiayangao and Shijiawan villages, near the town of Sandu, Guizhou Province, China (GPS coordinates N $26^{\circ} 01.814^{\prime}$ E $107^{\circ} 48.637^{\prime}$; Fig. 1). Approximately $80 \mathrm{~m}$ of blue-gray shale and yellow-green shale and siltstone of the Tonggao Formation is exposed along the track, of which the lowest $30 \mathrm{~m}$ contains exceptionally preserved fossils (Muir et al. in press) together with shelly taxa including conulariids and Sphenothallus. The rocks are of early Floian age (Zhang in Zhan \& Jin 2008), with the sampled beds occurring in the Tetragraptus approximatus Biozone (Fig. 1).

More than 50 species of invertebrates and algae have so far been collected from this section in the Tonggao Formation (Muir et al. 2011). The most abundant organisms are rhynchonelliformean and linguliformean brachiopods, disarticulated echinoderms (cystoids and possible eocrinoids or crinoids), dendroid graptolites, graptoloids, trilobites and bivalved arthropods. Gastropods, tergomyans, bryozoans, hyoliths and sponge spicules are also present, but in low numbers. A variety of trace fossils (horizontal burrows up to $5 \mathrm{~mm}$ wide) and agglutinated tubes occur at several 
levels. Less easily preservable taxa include algae, palaeoscolecidan worms and a possible nematode (Muir et al. in press), and non-biomineralizing arthropods.

The taphonomy of the Tonggao fossils varies according to their original composition, and overall the taphonomic style is a mixture of organic, mouldic and early diagenetic iron-mineral preservation. Originally phosphatic groups (conulariids, Sphenothallus, phosphatic brachiopods and palaeoscolecids) are preserved as flattened moulds. Elemental mapping of conulariids has shown that the original phosphate has been dissolved, and in some specimens there is a thin coating of weathered iron minerals replacing it.

Zhan \& Jin (2008) interpreted the Tonggao Formation as being deposited in a deep-water environment becoming shallower towards the top of the formation, based on the brachiopod faunas. The presence in the studied section of numerous small (millimetre-scale) clay mineral concretions in the beds above those sampled for fossils indicates an environment that was restricted and hypersaline, although deep-water (Izawa et al. 2012). However, the fossil-bearing beds were deposited in a more standard marine environment; the echinoderms and other groups indicate normal marine salinity. The abundant benthos, such as brachiopods, dendroid graptolites and agglutinated tubes, as well as the occurrence of burrows, indicates that the sea floor was oxygenated. The presence of abundant algae points to deposition in the photic zone. Thus, the abundantly fossiliferous beds in the lower part of the Tonggao Formation were deposited in a normal marine environment, but in an area that was prone to becoming isolated from the open ocean, resulting in intermittent hypersaline conditions.

The presence of articulated trilobite moults, agglutinated tubes, burrows and probable coprolites in many of the studied beds indicates that, in general, the preserved biota has undergone little or no transport. In some beds in the upper part of the studied section, abundant disarticulated echinoderm ossicles, occasionally in lenses, signify that there was some degree of transport. In most of the beds, however, such lenses are absent and there is no sign of winnowing or concentration of fossil remains. We therefore consider that the preserved biota largely represents organisms that were living in or very close to the area where they were buried.

\section{Systematic palaeontology}

Phylum Cnidaria Hatschek, 1888

Subphylum Medusozoa Peterson, 1979

Class Scyphozoa Götte, 1887

\section{Genus Conulariella Bouček, 1928}

\section{Conulariella sp.}

Figure $2 \mathrm{~A}-\mathrm{F}$

Horizon and locality. - Tonggao Formation (Lower Ordovician, lower Floian, Tetragraptus approximatus Biozone); near the town of Sandu, Guizhou Province, People's Republic of China.

Material. - Forty-seven nearly complete and partial specimens (NIGP 156022 to NIGP 156041, NIGP156059 to NIGP156067).

Description. - Specimens flattened, with the major faces nearly pressed against each other and the minor faces largely obscured; nearly complete specimens (Fig. 2B) gently curved, ranging from approximately $7 \mathrm{~mm}$ long and $2.5 \mathrm{~mm}$ wide (maximum single face width) to approximately $24 \mathrm{~mm}$ long and $12 \mathrm{~mm}$ wide (maximum single face width), bluntly terminated at the apical end (apex is missing) but with a minimum single face width as low as approximately $0.2 \mathrm{~mm}$ (Fig. 2E); some partial specimens originally at least $50 \mathrm{~mm}$ long. Apertural margin nearly straight (Fig. 2A, B). Angle of expansion (apical angle) of the major faces varies both between and within specimens, ranging from approximately $20-35^{\circ}$ within several $\mathrm{mm}$ of the former apex; in curved specimens, the apical angle decreases toward the apertural end, where it ranges from approximately $5-20^{\circ}$; apical angle of the minor faces much smaller than that of the major faces, though difficult to measure owing to compaction.

Transverse ribs strongly trochoidal (Fig. 2F), nodes and interspace ridges absent; transverse ridges number approximately 8 per mm near the apex, elsewhere generally numbering from 2-4 per $\mathrm{mm}$; also near the apex, some specimens show additional, finer and more closely spaced (approximately 5 per transverse rib), sinusoidal transverse ridges superimposed on the coarser trochoidal ribs; again near the apex, transverse ribs on the major faces straight in their central part but recurved adapically near the corners, elsewhere straight over essentially their entire length; geometry of the transverse ribs on the minor faces apparently similar to that on the major faces; facial midline unmarked, with no disruption of the transverse ribs; transverse ribs terminate along the shoulders of the corner sulcus, with the ends of the transverse ribs of the major faces arranged in opposition to the ends of the transverse ribs of the minor faces. Corner sulcus narrow, smooth, angular; internal corner and midline carina(e) absent; schott (apical wall) also absent.

Comparisons. - The original description of the type species, C. robusta, is based on six specimens (Bouček 1928), and those of the other three species are based on single specimens, all incomplete (Želízko 1911, 1921; Pillet \& Beaulieu 
1998). Indeed, the number of specimens here examined exceeds the total number of specimens previously described from Europe by about four to one. Furthermore, nearly all previously published illustrations of Conulariella are too poor to permit detailed comparisons of all species-level characters with the Tonggao Formation material, and previous descriptions omit many of the items presented in this report. Thus, pending direct examination of specimens from Europe as part of a comprehensive review of the genus Conulariella, we prefer to leave the Tonggao Formation specimens unassigned at the level of species.

Discussion. - Conulariella differs from all other known conulariids in having its transverse cross section strongly rectangular and in having nearly rectilinear transverse ribs and interspaces lacking any trace of a facial midline. In conulariids in which the transverse cross section is more or less square, flattened specimens present two approximately equally wide faces when viewed perpendicular to their greatest width. In contrast, flattened specimens of Conulariella, including those here and previously documented, present mostly a single major (wide) face, which generally has been pressed more or less straight down onto the opposing major face, obscuring the two minor (narrow) faces. Flattening of the Tonggao Conulariella specimens has made it difficult to determine the relative widths of their major and minor faces, but if the specimen shown in Fig. 2C does indeed show a single major face to the right of a single minor face, then the major : minor width ratio (in this specimen at least) is about $3: 1$.

Approximately 15 of the 47 Conulariella specimens examined here collectively occur in three small, non-radial clusters (Van Iten \& Cox 1992), each consisting of from four to seven specimens in an area ranging from about 4-10 $\mathrm{cm}^{2}$, on or very close to a common (nearly) level plane of fissility (Fig. 2D). The specimens range from (apparently) nearly complete to fragmentary, with fragments consisting in some cases of part of a single corner. Each such cluster occurs in blue-gray or yellow-green shale that also contains carbonized graptolites and/or orbiculoid brachiopods. As noted above, the fine-grained lower part of the Tonggao Formation probably was deposited under conditions of low physical energy. This suggests that the Conulariella clusters may reflect an original clustered or clumped distribution. The fragmentary state of some specimens raises the possibility of secondary concentration of Conulariella remains by currents, but the fact that the clusters do not contain other organisms indicates that formation of the clusters by transport is unlikely.

The geometry of the apertural margin of Conulariella has not been fully addressed by previous authors (e.g., Bouček 1928, Pillet \& Beaulieu 1998). This matter is important because it bears on whether Conulariella, like other conulariids, could close the apertural end of its periderm and thus retract and cover exposed soft parts. One possibility is that the apertural margin paralleled the transverse ribs, being mostly straight but with moderate to slight adapical recurvature near the corners. Another possibility is that the apertural margin of any one face cross-cut the transverse ribs, forming a triangular or lobate facial lappet that projected beyond the ends of the corners (e.g., Moore \& Harrington 1956b, fig. 43.2). Inspection of photographs of apparent complete specimens from Bohemia (e.g., Bouček 1939, pl. 3, fig. 14), as well as actual specimens from the Tonggao Formation (e.g., Fig. 2A, B), suggests that the apertural margin was mostly straight, and that apertural lappets were either absent or projected only very slightly beyond the ends of the corners. Thus, in all specimens that appear to preserve the apertural end, the apertural edge parallels the nearest transverse ribs, which again are straight. No specimens previously documented or that we have seen from the Tonggao Formation exhibit triangular or lobate lappets that project beyond the ends of the corners. Those specimens that do not exhibit a straight apertural edge instead exhibit an irregular edge that probably is an artifact of breakage. Therefore unlike many other conulariids, some with transverse ribs or node rows that are strongly arched as opposed to straight, Conulariella could not cover the apertural end by simple bending of four discrete lappets along their base (e.g., Moore \& Harrington 1956b, fig. 43.3). The only possible way Conulariella could have covered the aperture would have been through a kind of plicated closure (Moore \& Harrington 1956b, Van Iten et al. 2008), in which the corners are also bent and the faces are folded in the manner of the spout of a paper milk carton (Moore \& Harrington 1956b, fig. 45). At this point, none of the Conulariella specimens thus far collected appears to show plicated closure, suggesting that the oral end of the Conulariella periderm was always open (meaning that the soft body at this end was always exposed).

\section{?Conulariid gen. et sp. indet.}

Figure $3 \mathrm{~A}, \mathrm{~B}$

Horizon and locality. - Tonggao Formation (Lower Ordovician, lower Floian, Tetragraptus approximatus Biozone); near the town of Sandu, Guizhou Province, People's Republic of China.

Material. - Four specimens, including one specimen consisting of both part and counterpart (NIGP 156042-NIGP 156045).

Description. - Possible flattened conulariids lacking nodes or features clearly homologous with transverse ribs on the putative faces, which appear to be bordered by a narrow shallow sulcus. Angle of expansion of the most complete 

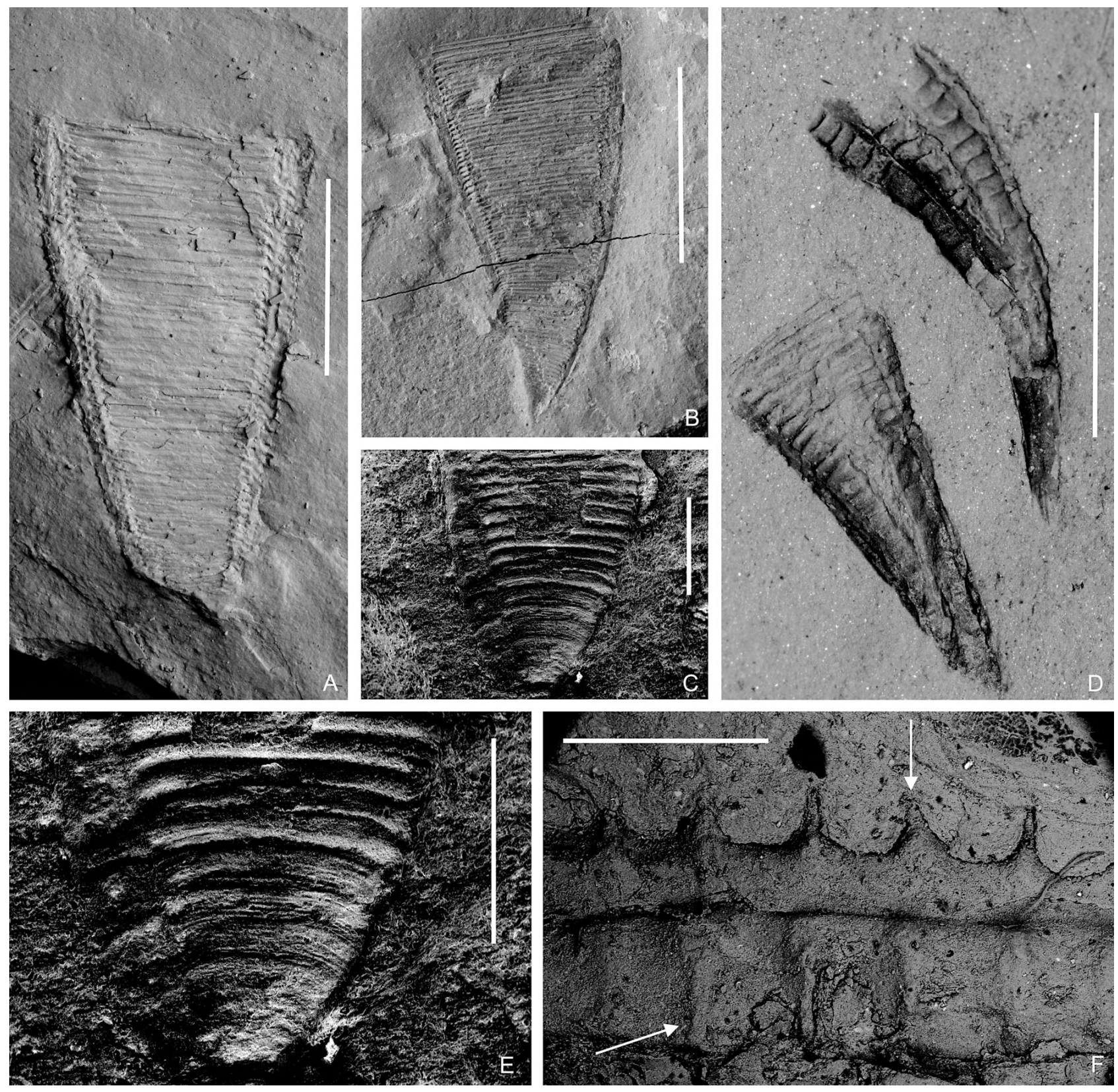

Figure 2. Conulariella sp. All specimens from the Xiayangao section, Guizhou; Tetragraptus approximatus Biozone, Floian, Ordovician; Tonggao Formation. Distances above Guotang Formation: A $22.1 \mathrm{~m}$, B 9.5m, C-F $21.4 \mathrm{~m}$. A - NIGP 156024, major face of a partially complete specimen, showing gentle curvature of the corners (with one corner more strongly curved than the other) and the straight transverse ribs and apertural margin. $\bullet$ B - NIGP 156039, major face of a nearly complete specimen, showing pervasive Fe-staining, gentle curvature of the corners (with one corner more strongly curved than the other), and the straight transverse ribs and apertural margin. $\bullet \mathrm{C}, \mathrm{E}-\mathrm{NIGP} 156065 \mathrm{C}$ is an SEM photomicrograph (secondary electron mode) of a major face of a small specimen broken just a few $\mathrm{mm}$ above the former apex. E is detail of the apical end of the same specimen, showing the fine, closely spaced, sinusoidal transverse ridges superimposed on the coarser transverse ribs, which exhibit adapical recurvature near their two ends. $\bullet$ D - NIGP $156031 \mathrm{~A}, \mathrm{~B}$, two specimens forming part of a non-radial cluster of seven specimens situated within an area of approximately $10 \mathrm{~cm}^{2} \cdot \bullet \mathrm{F}-\mathrm{NIGP} 156041$, SEM photomicrograph (backscattered electron mode) of part of a corner of another specimen, showing the strongly trochoidal transverse ribs in longitudinal section (vertical arrow) and the narrow, angular corner sulcus (oblique arrow). Scale bars: A, B = $10 \mathrm{~mm}, \mathrm{C}, \mathrm{E}, \mathrm{F}=1 \mathrm{~mm}, \mathrm{D}=5 \mathrm{~mm}$.

specimen ranges from approximately $40^{\circ}$ near the apex to approximately $20^{\circ}$ near the wide (apertural) end. Specimens range from approximately $8.5 \mathrm{~mm}$ long and $5 \mathrm{~mm}$ wide to approximately $25 \mathrm{~mm}$ long and $13 \mathrm{~mm}$ wide; in transverse section, specimens exhibit swell and swale topography (possible alternating rounded corners and faces); two specimens (about 8.5 and $14 \mathrm{~mm}$ long, respectively) show apparent fine, closely spaced, subdued, sinusoidal 
transverse ridges; another specimen (Fig. 3B) shows two sets of several fine, chevron-like grooves or ridges that point toward the wide end of the fossil. Possible apertural margin mostly irregular (broken), though one specimen shows a possible triangular lappet in the central portion of the margin. Pointed apical end of two specimens situated immediately adjacent to an orbiculoid brachiopod valve.

Discussion. - Identification of these specimens as possible conulariids is based primarily on their overall elongate triangular shape and on the possible presence of a corner and/or midline sulcus, and possible transverse ridges. The differences in transverse ornament between the particular specimens mentioned above in the description may indicate that they represent two different species.

Two of the four specimens described above taper to a fine point $(<0.1 \mathrm{~mm}$ wide) situated within a few millimetres of an orbiculoid brachiopod (Fig. 3A), which are not common in the Tonggao fauna. Similar associations described for other conulariids have been interpreted as evidence of apical attachment of conulariids to hard biological substrates (e.g., Van Iten et al. 1996, pl. 1, fig. 8).

Phylum Cnidaria Hatschek, 1888

Subphylum Medusozoa Peterson, 1979

Class uncertain

\section{Genus Sphenothallus Hall, 1847}

\section{Sphenothallus sp.}

Figure $3 \mathrm{C}-\mathrm{F}$

Horizon and locality. - Tonggao Formation (Lower Ordovician, lower Floian, Tetragraptus approximatus Biozone); near the town of Sandu, Guizhou Province, People's Republic of China.

Material. - Eighteen partial specimens, specimen numbers NIGP 156046-NIGP 156058.

Description. - Partial tubules up to approximately $50 \mathrm{~mm}$ long and $3.5 \mathrm{~mm}$ wide, original length of complete tubules considerably greater; tubules lamellar (Fig. 3F), gently curved in the plane of the two longitudinal thickenings (Fig. 3C, D), tapered (angle of expansion $<5^{\circ}$ ); transverse cross section of the most complete tubules subcircular in the apical region (within about $20 \mathrm{~mm}$ of the former apex), elsewhere subelliptical (Fig. 3F); tubule wall between the longitudinal thickenings very thin, unornamented. Basal holdfast not preserved, apical wall absent.

Discussion. - This is the first report of Sphenothallus, a probable thecate scyphozoan or hydrozoan (Van Iten et al.
1992), from the Ordovician System of China. Previously this genus was known in China from several localities and rock units in the Lower-Middle Cambrian (e.g., Zhu et al. 2000, Li et al. 2004) and in the Silurian System (Wang et al. 2003). Owing to the incompleteness and relatively poor preservation of the Tonggao Formation specimens, we cannot determine to which species they belong.

\section{Discussion}

\section{Comparison with other Early Ordovician faunas}

Sphenothallus co-occurs with conulariids in a number of Palaeozoic rock formations ranging in age from Middle Ordovician to Mississippian (e.g., Van Iten \& Cox 1992, Van Iten et al. 1996, Brabcová \& Kraft 2003, Botting \& Muir 2012). Indeed, it appears that wherever one of these taxa occurs the other also is likely to be present. For example, many sites in the Lower Ordovician Klabava Formation of the Prague Basin contain Conulariella as well as other conulariids and Sphenothallus (Kraft \& Kraft 1992, 1993, 1994). The Tremadocian-Floian Fezouata Biota of southeastern Morocco also contains both groups. One Sphenothallus specimen was incorrectly identified as a tubiculous worm by Van Roy et al. (2010, fig. S2A), and the deposit also contains Archaeoconularia sp. and an indeterminate conulariid that appears to be most similar to the possible conulariid here documented (Van Iten, unpublished observations). In the Tonggao Formation, Sphenothallus and Conulariella occur in similar lithologies, and in some cases in the same sample (Fig. 4).

\section{Palaeobiogeographical implications}

Conulariella is now known from three Early-Middle Ordovician terranes: Armorica (northwestern France), Perunica (Bohemia) and South China (Fig. 5). Sphenothallus is known from South China, Morocco (North Gondwana) and Bohemia, as well as from Middle-Late Ordovician strata of cratonic Laurentia and peri-Laurentia (Girvan area, southwestern Scotland; Van Iten, unpublished observations), and Middle Ordovician (latest Darriwilian) strata of Avalonia (Botting \& Muir 2012). It is possibly also present in Late Ordovician strata of Baltica (Serpulites kukersiamus and S.? longissimus; Öpik 1927). In the Early Ordovician, Armorica and Perunica were high latitude peri-Gondawanan terranes attached or situated very close to present-day northwest Africa (Fatka \& Mergl 2009). All three of these areas were part of the Mediterranean Province during the Ordovician, and there are close faunal similarities between the Arenig (Floian) faunas of Armorica 

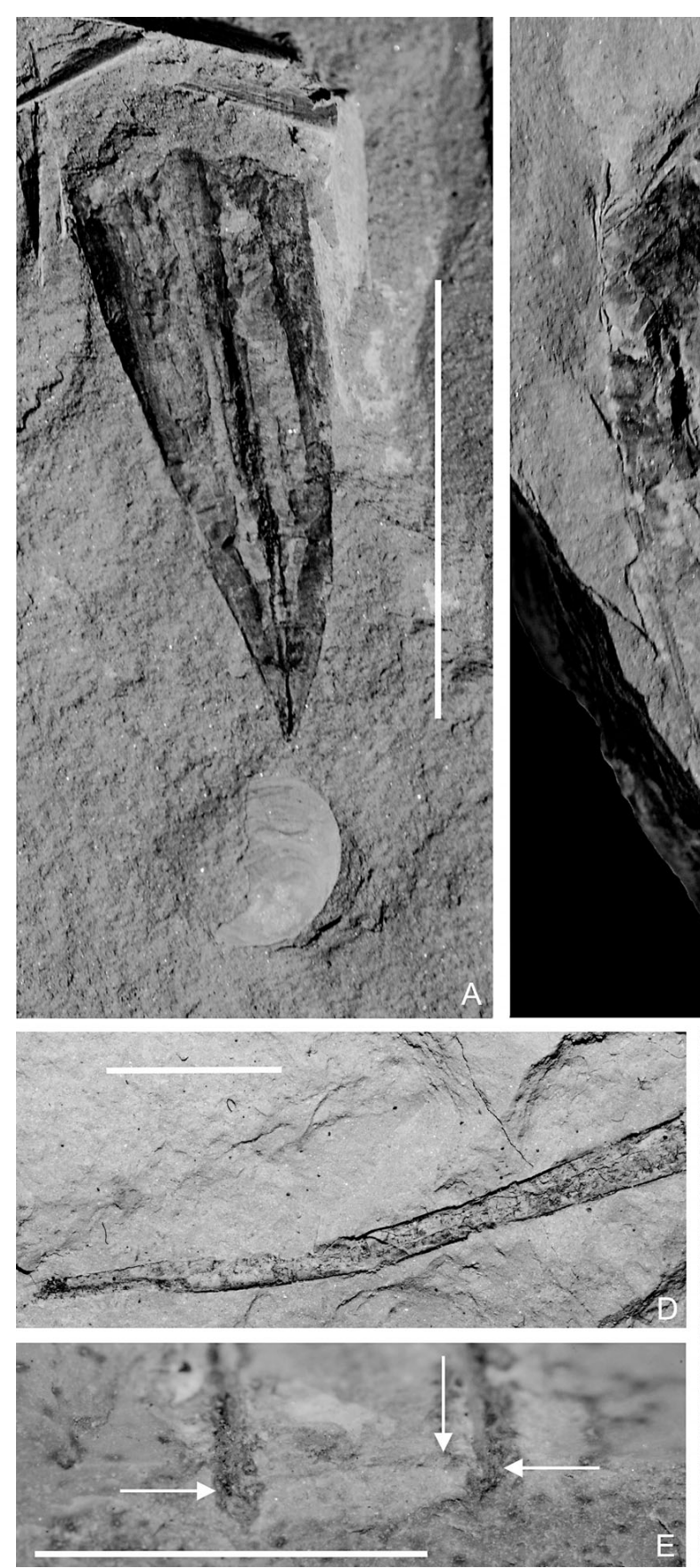

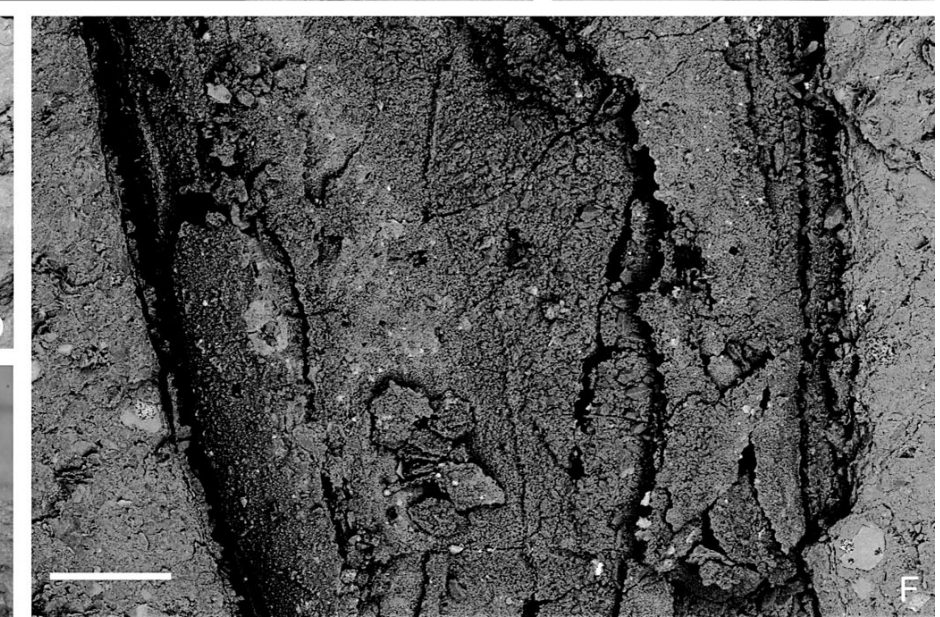

Figure 3. Conulariid sp. and gen. indet. and Sphenothallus sp. All specimens from the Xiayangao section, Guizhou; Tetragraptus approximatus Biozone, Floian, Ordovician; Tonggao Formation. Distances above Guotang Formation: A, B 23 m, C 24.5 m, D 21.4 m, E 10 m, F 23 m. - A, B - conulariid sp. and gen. indet.; A - NIGP 156042, apparently nearly complete specimen, possibly with two faces exposed and with the pointed apical end situated in close proximity to an orbiculoid brachiopod; B - NIGP 156044, partial specimen, showing chevron-like transverse lines possibly homologous to conulariid transverse ribs. $\bullet \mathrm{C}-\mathrm{F}-$ Sphenothallus sp.; C-NIGP 156053, portion of an Fe-stained tubule fragment, again with the two longitudinal thickenings preserved largely as moulds; D - NIGP 156055, portion of the most complete tubule, showing very gentle tapering and with the two longitudinal thickenings largely preserved as moulds; E - NIGP 156052, view of a broken end of Sphenothallus, showing the two longitudinal thickenings (horizontal arrows) and the extremely thin peridermal wall between them (vertical arrow) in transverse crossection; F - NIGP 156050, SEM photomicrograph (secondary electron mode) of one of the smallest specimens, showing relic fine lamination. Scale bars: A-C $=10 \mathrm{~mm}, \mathrm{D}, \mathrm{E}=5 \mathrm{~mm}$, $\mathrm{F}=200 \mu \mathrm{m}$. 


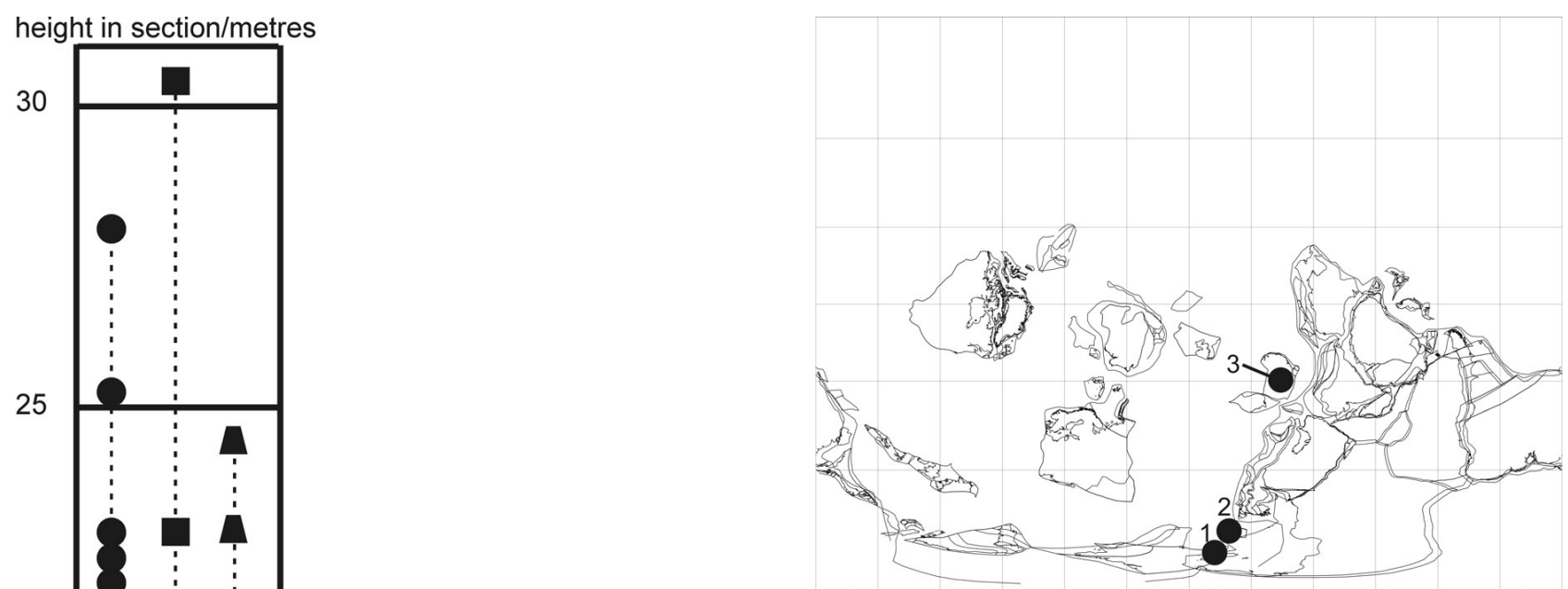

Figure 5. Palaeogeographical reconstruction for the earliest Floian (478 Ma) showing the currently known distribution of Conulariella. 1 = Armorica, 2 = Perunica, 3 = South China. Locality 3 and Morocco (near Armorica) also yield earliest Floian Sphenothallus sp. Map drawn using BugPlates (Torsvik 2009) and modified after Cocks \& Torsvik (2013).

and Perunica (Havlíček et al. 1994). It should also be noted that Perunica is considered by at least some authors (Servais \& Sintubin 2009) to be merely a faunal province on the edge of Gondwana, rather than a separate microcontinent.

Regarding South China, some previous palaeogeographical reconstructions (e.g., Torsvik \& Cocks 2009) have shown this as a separate terrane that straddled the palaeoequator and was situated most closely to the Sibumasu terrane, which probably was a part of core Gondwana. However, a more recent reconstruction (Cocks \& Torsvik 2013) places South China at approximately $30^{\circ}$ South, and close to Gondwana.

The co-occurrence of Sphenothallus in early Floian strata of South China and Morocco, and of Conulariella in Floian-Darriwilian rocks of South China, Perunica and Armorica, tends to corroborate the hypothesis that the terranes in question were in (relatively) close faunal communication with each other during Early-Middle Ordovician times. This is in agreement with previous observations based on Middle Ordovician echinoderms, which showed faunal similarities between Baltica, Bohemia, Morocco, Sibumasu and South China (Lefebvre et al. 2005). If South China had been situated as postulated by Torsvik \& Cocks (2009), with South China astride the palaeoequator and

Conulariella

Sphenothallus

Conulariid gen. et sp. indet.

Figure 4. Distribution of Conulariella, Sphenothallus and conulariid gen. et sp. indet. in the Xiayangao section. The entirety of the section is in the Tonggao Formation (Tetragraptus approximatus Biozone, earliest Floian). The zero metre level is at the contact with the underlying Guotang Formation.
Perunica and Armorica located within $20^{\circ}$ of the South Pole, then Early Ordovician (early Floian) Conulariella and Sphenothallus boasted a palaeolatitudinal range of approximately $70^{\circ}$. Even in a world presumably as warm and (thus) equable as that of the early Ordovician (Barnes 2004), this would seem fairly remarkable. Thus, our data on the distribution of Conulariella and Sphenothallus (Fig. 5) are in accordance with a newer palaeogeographical reconstruction (Cocks \& Torsvik 2013), in which South 
China is placed further to the south (nearer to Armorica and Perunica), and all three terranes are next to the edge of Gondwana. On this basis, Conulariella should also occur in the Afghan terrane and the Lut and Alborz blocks (modern Iran), all of which were situated on the edge of Gondwana between South China and Perunica/Armorica (Cocks \& Torsvik 2013).

\section{Conclusions}

(1) Conulariids and Sphenothallus co-occur in several Early Ordovician communities, including the South China assemblage described here.

(2) One of the Tonggao Formation conulariids, Conulariella sp., also occurs in Early and Middle Ordovician strata of Bohemia (Perunica) and younger (Darriwilian) strata in northwestern France (Armorica). Both of these terranes were attached to North Gondawana at high latitudes and in close proximity to each other. South China was further to the north and next to Gondwana, implying that Conulariella could disperse along the Gondwanan margin.

\section{Acknowledgments}

This study was partially supported by a grant from the Hanover College Faculty Development Committee to HVI, the China Postdoctoral Science Foundation, No. 20110490136 to LAM, the Chinese Academy of Sciences Fellowships for Young International Scientists grant No. 2010Y2ZA03 and the National Natural Sciences Foundation of China Young International Fellowships, No. 41150110152 to JPB, and by the Project-Oriented Hundred Talents Programme (No. KZCX2-YW-BR-23) to JPL. The invaluable assistance in the field of $\mathrm{Ng}$ Tin-Wai, Li Xiangfeng and Yang Zaichun is gratefully acknowledged. Yan Fang is thanked for assistance with the SEM in Nanjing. HVI thanks Susan Butts for permission to examine Fezouata Biota conulariids and Sphenothallus in collections of the Peabody Museum, Yale University. Finally, the authors thank Petr Kraft and Olef Vinn for their constructive reviews of the original manuscript. This paper is a contribution to the International Geoscience Programme (IGCP) Project 591 - The Early to Middle Paleozoic Revolution.

\section{References}

BARNES, C.R. 2004. Ordovician oceans and climate, 72-76. In Webby, B.D., Paris, F., Droser, M.L. \& Percival, I.C. (eds) The Great Ordovician Biodiversification Event. Columbia University Press, New York.

BARRANDE, J. 1867. Système silurien du centre de la Bohême. Ière partie, Tome 3. Classe des Mollusques, Ordre des Ptéropodes. 179 pp. Chez l'auteur et éditeur, Prague \& Paris.

Botting, J.P. \& Muir, L.A. 2012. Fauna and ecology of the Holothurian Bed, Llandrindod, Wales, UK (Darriwilian, Mid- dle Ordovician), and the oldest articulated holothurian. Palaeontologia Electronica 15(1), 9A, 1-28,

http://palaeo-electronica.org/content/2012-issue-1-articles/ 191-welsh-holothurian-bed.

BouČEK, B. 1928. Révision des Conulaires paléozoïques de la Bohême. Palaeontographica Bohemiae 11, 60-108.

Bouček, B. 1939. Conularida, A113-A131. In Schindewolf, O.H. (ed.) Handbuch der Paläozoologie 2A. Gebrüder Bornträger, Berlin.

BrabcovÁ, Z. \& Kraft, P. 2003. Study of conulariid and related phosphatic conical exoskeletons from the Prague Basin (Czech Republic), 263-266. In Albanesi, G.L., Beresi, M.S. \& Peralta, S.H. (eds) Ordovician from the Andes. INSUGEO, Serie Correlación Geológica 17.

Cocks, L.R.M. \& Torsvik, T.H. 2013. Earth geography from 500 to 400 million years ago: a faunal and palaeomagnetic review. Journal of the Geological Society, London 159, 631-644. DOI 10.1144/0016-764901-118

Conway Morris, S. \& Chen, M. 1992. Carinachitiids, hexangulaconulariids, and Punctatus: problematical metazoans from the Early Cambrian of South China. Journal of Paleontology 66, 384-406.

FatKa, O., Kraft, P. \& Szabad, M. 2012. A first report of Sphenothallus Hall, 1847 in the Cambrian of Variscan Europe. Comptes Rendus Palevol 11, 539-547. DOI 10.1016/j.crpv.2012.03.003

Fatka, O. \& Mergl, M. 2009. The 'microcontinent' Perunica: status and story 15 years after conception, 65-101. In BASSETT, M.G. (ed.) Early Palaeozoic Peri-Gondwana Terranes: New Insights from Tectonics and Biogeography. Geological Society of London, Special Publication 325.

GötTE, A. 1887. Entwicklungsgeschichte der Aurelia aurita und Cotylorhiza tuberculata. Abhandlungen zur Entwicklungsgeschichte der Tiere. Viertes Heft. 79 pp. Verlag von Leopold Voss, Hamburg \& Leipzig.

Hall, J. 1847. Paleontology of New York. Volume 1. Containing descriptions of the organic remains of the Lower Division of the New York system (equivalent to the Lower Silurian rocks of Europe). ix-xxix + 338 pp. C. Van Benthuysen, Albany.

HATSCHEK, B. 1888. Lehrbuch der Zoologie. Eine morphologische Ubersicht der Thierreiches zur Einfuhrung in das Stadium der Wissenschaft. Erste Liefrung. iv + 304 pp. Fischer, Jena.

Havlíček, V., VaněK, J. \& Fatka, O. 1994. Perunica microcontinent in the Ordovician (its position within the Mediterranean Province, series division, benthic and pelagic associations). Sborník geologických věd, Geologie 46, 23-56.

HE, Y.X. \& YANG, X.H. 1986. Early Cambrian coelenterates from Nanjiang, Sichuan. Bulletin of the Chengdu Institute of Geology and Mineral Resources 7, 31-43. [in Chinese, English summary]

IzAwa, M.R.M., Flemming, R.L., Zhan, R. \& Jin, J. 2012. Characterization of green clay concretions from the Tonggao Formation, South China: mineralogy, petrogenesis and paleoenvironmental implications. Canadian Journal of Earth Sciences 49, 1018-1026. DOI 10.1139/e2012-040

Kraft, J. \& Kraft, P. 1992. The Corymbograptus v-similis Biozone (Klabava Formation, Ordovician of Prague Basin). Folia Musei rerum naturalium Bohemiae occidentalis, Geologica 35, 1-26. 
Kraft, J. \& Kraft, P. 1993. The Holograptus tardibrachiatus Biozone (Klabava Formation, Ordovician of the Prague Basin). Folia Musei rerum naturalium Bohemiae occidentalis, Geologica 37, 1-34.

Kraft, J. \& KRAFT, P. 1994. The Azygograptus-Tetragraptus (reclinatus group) Biozone (Klabava Formation, Ordovician of the Prague Basin). Folia Musei rerum naturalium Bohemiae occidentalis, Geologica 40, 1-36.

Lefebvre, B., Ghobadipour, M. \& Nardin, E. 2005. Ordovician echinoderms from the Tabas and Damghan regions, Iran: palaeobiogeographical implications. Bulletin de la Société géologique de France 176, 231-242. DOI 10.2113/176.3.231

Leme, J.M., Simoes, M.G., Rodrigues, S.C., Van Iten, H. \& MarQUES, A.C. 2008. Major developments in conulariid research: problems of interpretation and future perspectives. Ameghiniana 45, 407-420.

Li, G.X., Zhu, M.Y., Van Iten, H. \& Li, C.W. 2004. Occurrence of the earliest known Sphenothallus Hall in the Lower Cambrian of Southern Shaanxi Province, China. Geobios 37, 229-237. DOI 10.1016/j.geobios.2003.04.002

Moore, R.C. \& Harrington, H.J. 1956a. Conulata, F54-F66. In Moore, R.C. (ed.) Treatise on Invertebrate Paleontology, Part F, Coelenterata. Geological Society of America \& University of Kansas Press, Boulder \& Lawrence.

Moore, R.C. \& Harrington, H.J. 1956b. Scyphozoa, F27-F38. In Moore, R.C. (ed.) Treatise on Invertebrate Paleontology, Part F, Coelenterata. Geological Society of America \& University of Kansas Press, Boulder \& Lawrence.

Muir, L.A., Botting, J.P., VAn Roy, P., Zhang, Y.D. \& Lin, J.P. 2011. A comparison of three early Ordovician Lagerstätten. GSA Abstracts with Programs 43(5), 54.

Muir, L.A., NG, T.W., Li, X.F., ZhANG, Y.D. \& Lin, J.P. in press. Palaeoscolecidan worms and a possible nematode from the Early Ordovician of South China. Palaeoworld.

ÖPIK, A.A. 1927. Beiträge zur Kenntnis der Kukruse-(C2-)Stufe in Eesti. II. Publications of the Geological Institution of the University of Tartu 10, 1-35.

Peterson, K.W. 1979. Development of coloniality in Hydrozoa, 105-139. In Larwood, G. \& Rosen, B.R. (eds) Biology and Systematics of Colonial Organisms. Academic Press, New York.

Pillet, J. \& Beaulieu, G. 1998. Some Middle and Upper Ordovician conulariids from the Armorican Massif. Bulletin de la Société des Sciences Naturelles de l'Ouest de la France 20, $29-40$.

Servais, T. \& Sintubin, M. 2009. Avalonia, Armorica, Perunica: terranes, microcontinents, microplates or palaeobiogeographical provinces?, 103-115. In BAsseTt, M.G. (ed.) Early Palaeozoic Peri-Gondwana terranes: new insights from tectonics and biogeography. Geological Society of London, Special Publications 325.

Tonsvik, T.H. 2009. BugPlates: Linking biogeography and palaeogeography. Available online at: http://www.geodynamics.no/Web/Content/Software (accessed 5 June 2010).

Torsvik, T.H. \& Cocks, R.M. 2009. The Lower Paleozoic palaeogeographical evolution of the northeastern and eastern
peri-Gondwanan margin from Turkey to New Zealand. Geological Society of London, Special Publications 235, 3-21. DOI 10.1144/SP325.2

VAn Iten, H. \& Cox, R.S. 1992. Evidence of clonal budding in a radial cluster of Paraconularia crustula (White) (Pennsylvanian: ?Cnidaria). Lethaia 25, 421-426.

DOI 10.1111/j.1502-3931.1992.tb01645.x

VAn Iten, H., Cox, R.S. \& MaPES, R.H. 1992. New data on the morphology of Sphenothallus Hall: implications for its affinities. Lethaia 25, 135-144. DOI 10.1111/j.1502-3931.1992.tb01378.x

Van ItEn, H., FitzKe, J.A. \& Cox, R.S. 1996. Problematical fossil cnidarians from the Upper Ordovician of the north-central USA. Palaeontology 39, 1037-1064.

Van Iten, H., Konate, M. \& Moussa, Y. 2008. Conulariids of the upper Talak Formation (Mississippian, Visean) of northern Niger (West Africa). Journal of Paleontology 82, 192-196. DOI 10.1666/06-083.1

Van Iten, H., Leme, J.M., Simões, M.G., Marques, A.C. \& ColLINS, A.G. 2006. Reassessment of the phylogenetic affinities of conulariids (?Ediacaran-Triassic) within the subphylum Medusozoa (phylum Cnidaria). Journal of Systematic Palaeontology 4, 109-118. DOI 10.1017/S1477201905001793

Van Iten, H. \& Vyhlasová, Z. 2004. Conulariids, 119-123. In Webby, B.D., Paris, F., Droser, M.L. \& Percival, I.C. (eds) The Great Ordovician Biodiversification Event. Columbia University Press, New York.

VAn Iten, H., Zhu, M.Y. \& Li, G.X. 2010. Redescription of Hexaconularia He and Yang, 1986 (Lower Cambrian, South China): implications for the affinities of conulariid-like small shelly fossils. Palaeontology 53, 191-199. DOI 10.1111/j.1475-4983.2009.00925.x

Van Roy, P., OrR, P.J., Botting, J.P., Muir, L.A., Vinther, J., Lefebvre, B., el Hariri, K. \& Briggs, D.E.G. 2010. Ordovician faunas of Burgess Shale type. Nature 465, 215-218. DOI 10.1038/nature09038

WANG, Y., HAO, S.G., Chen, X., Rong, J.Y., Li, G.X., LiU, J. \& Xu, H. 2003. Sphenothallus from the Lower Silurian of China. Journal of Paleontology 77, 583-588. DOI 10.1666/0022-3360(2003)077<0583:SFTLSO>2.0.CO;2

ŽelízKo, J.V. 1911. Neue Pteropoden des älteren Paläozoikums Mittelböhmens. Jahrbuch der Kaiserlich-königlichen geologischen Reichsanstalt 61, 41-52.

ŽelízKo, J.V. 1921. Äquivalente der untersilurischen EulomaNiobe fauna bei Plzenec in Böhmen. Videnskabs-selskabet $i$ Christiania, Matematisk-naturvidenskabelig Klasse, Skrifter 2, 1-27.

ZHAN, R. \& JIN, J. 2008. Onshore migration of a deep-water brachiopod fauna from the Lower Ordovician Tonggao Formation, Jiangnan Slope, southeastern Guizhou Province, South China. Canadian Journal of Earth Sciences 45, 141-157. DOI 10.1139/E07-043

Zhu, M.Y., Van Iten, H., Cox, R.S., Zhao, Y.L. \& Erdtmann, B.-D. 2000. Occurrence of Byronia Matthew and Sphenothallus Hall in the Lower Cambrian of China. Paläontologische Zeitschrift 74, 227-238.

DOI 10.1007/BF02988098 